\title{
TRENDS IN VACCINOLOGY EDUCATION OF NURSES IN POLAND
}

\section{TRENDY PIELĘGNIARSKIEJ EDUKACJI WAKCYNOLOGICZNEJ W POLSCE}

\author{
${ }^{1}$ Chair and Department of Pediatric Nursing, Faculty of Nursing and Health Sciences, Medical University of Lublin \\ ${ }^{2}$ Head of Chair and Department of Pediatric Nursing, Faculty of Nursing and Health Sciences \\ Medical University of Lublin
}

S u m m a r y

Introduction. The tangible result of the successful implementation of immunoprophylaxis is properly organized and conducted education on vaccinology of parents and people to be vaccinated, which should be carried out by medical professionals of different specialties, including nurses performing vaccinations.

A i m. Presentation of trends in the development of vaccinology education of nurses in Poland.

Material and methods. Overview of Polish and foreign medical literature in the years 2000-2014 on education of society by medical personnel in the field of active immunization.

Results. Changes in the immunoprophylaxis in Poland, the aim of which is further development of Immunization Program in accordance with trends in many European countries, necessitate ongoing vaccinology education. This requires from the medical staff (a doctor and a nurse) not only current knowledge about vaccination, but also the ability to communicate effectively and build a feeling of trust in the relationship with patients. The theoretical foundation of modern vaccinology education should be viewing it as a process, the outcome of which is to achieve competences of the trainee to express judgments and make effective decisions on matters related to immunization.

Conclusions. 1. Educational activities of medical personnel in the field of immunization are crucial for the social acceptance of this method of infectious diseases prevention. 2. Effective implementation of vaccinology education by medical personnel requires continuing professional and personal development as well as interpersonal communication skills. 3. Appointment of the vaccinology educators and interdisciplinary method of implementation of education on vaccination may be a desirable trend in the development of active immunization.

\section{Streszczenie}

W stęp. Wymiernym efektem skutecznej realizacji immunoprofilaktyki jest prawidłowo zorganizowania i przeprowadzona edukacja wakcynologiczna rodziców oraz osób podlegających szczepieniu, która powinna być udziałem pracowników medycznych różnych specjalności, w tym także pielęgniarek wykonujących szczepienia.

Cel pracy. Przedstawienie trendów w rozwoju pielęgniarskiej edukacji wakcynologicznej w Polsce.

Materiał i metoda. Przegląd polskiego i zagranicznego piśmiennictwa medycznego w latach 2000-2014 na temat edukacji społeczeństwa przez personel medyczny w zakresie czynnej immunizacji.
Wyniki. Zmiany dotyczące immunoprofilaktyki w Polsce, której celem jest dalszy rozwój Programu Szczepień Ochronnych zgodnie $\mathrm{z}$ trendami wielu państw europejskich, stwarza potrzebę permanentnej edukacji wakcynologicznej. Wymaga to od personelu medycznego lekarza i pielęgniarki nie tylko aktualnej wiedzy na temat szczepień, ale również umiejętności efektywnego komunikowania się i budowania klimatu zaufania w relacjach $\mathrm{z}$ podopiecznymi. Teoretycznym założeniem nowoczesnej edukacji wakcynologicznej powinno być postrzeganie jej jako procesu, wynikiem którego jest uzyskanie kompetencji edukowanego do wyrażania sądów i podej- 
mowania skutecznych decyzji w sprawach dotyczących szczepień ochronnych.

Wnioski. 1. Edukacyjna działalność personelu medycznego w zakresie szczepień ochronnych ma decydujące znaczenie dla społecznej akceptacji tej metody profilaktyki chorób zakaźnych. 2. Skuteczne realizowanie edukacji wakcynologicznej przez personel medyczny

Key words: nursing education, vaccination

Stowa kluczowe: edukacja pielęgniarska, szczepienia

\section{INTRODUCTION}

Vaccination is the most effective and unquestionable method of infectious diseases prevention of every person regardless of their age and gender. The immediate objective of mass vaccination is primarily individual protection against the disease by creating individual's resistance, while the epidemiological effect is the elimination and eradication of the disease [1].

Vaccinations are an important link in the multidirectional health policy of each country. Every country in the world has developed its own strategies for immunization, which arise from the economic, political, sociological, geographical and epidemiological risks prevailing in the area [2].

Optimal implementation of immunization requires both deliberate legal and organizational regulations and effective educational action on contemporary opportunities of infectious diseases immunoprophylaxis [3, 4].

The aim of the research is a presentation of trends in the development of vaccinology education of nurses in Poland.

\section{MATERIAL AND METHODS}

Overview of Polish and foreign medical literature in the years 2000-2014 on education of society by medical personnel in the field of active immunization.

\section{TRENDS AND QUANTIFIABLE BENEFITS OF IMMUNIZATION}

The functioning of Immunization Program (IP) in each country depends on the type of healthcare management, hence its implementation is done in the centralized, decentralized, or mixed form [1].

In a centralized system, all vaccinations are free of charge and voluntary, centrally funded and administered. The examples of countries in which this wymaga stałego doskonalenia zawodowego i rozwoju osobowego, a także umiejętności komunikacji interpersonalnej. 3. Powołanie edukatorów wakcynologicznych oraz interdyscyplinarny sposób realizacji edukacji na temat szczepień może stanowić pożądany trend w rozwoju czynnej immunizacji.

model operates is England, where vaccinations are performed by family doctors, and Finland, where the adequately prepared nurses are involved in vaccination. In contrast, a decentralized system of vaccination is present in Germany and France. In these countries, vaccinations are performed in private doctor's offices, but a family doctor or pediatrician makes the decision about the choice of the vaccine and its purchase is financed by private insurance companies [2].

Polish Immunization Program is of mixed type. It consists of compulsory vaccinations, which are executed in a centralized system (children and young people and people particularly vulnerable to infections), and the recommended vaccinations implemented without financial support from the state, i.e. in a decentralized system [5].

Regardless of the model of the Immunization Program (IP) in the country, vaccinations bring individual and social benefits. First of all, they prevent infectious diseases and often their lethal complications. They affect the evolution of resistance of population and generate savings in social-health benefits and for the health care system by reducing the number of medical visits and expenditure on hospitalization. Thereby, they enhance the quality of family and social life, preventing exclusion due to illness and its consequences [6].

World Health Organization has an impact on the system of immunization programs in certain countries. It integrates international cooperation in the fight against infectious diseases and sets global guidelines and goals that are followed by all countries of the European Union in the construction of immunization programs [2].

Polish mandatory IP includes minimum of vaccinations that every child should receive. Due to the fact that their basic panel is implemented in the first two years of life, parents' desire to exercise extra recommended immunizations may pose some 
difficulties. In this case for the child to get vaccinations specified in the recommended IP, the extra, fourth injection should be performed during a routine visit in a vaccination office. However, postponing to another date at least one of the mandatory vaccination interferes with their whole scheme and increases the likelihood that the child will not receive them in time [7].

An alternative that optimizes implementation of the IP are formulations of combined vaccines. They facilitate an application of several microbial antigens and getting resistance against these diseases in one injection. The multivalent highly combined vaccines provide immunization against more than three different infectious diseases. On the basis of the combined DTP vaccine, four-, five-, and six-component vaccines have been developed that can be selected so as to bring them in place of the monovalent vaccines contained in the mandatory IP. Not without significance is the fact that the combined vaccines by reducing the number of injections decrease the amount of injected preservatives and adsorbents contained in all vaccines. The highly combined vaccines have specific application in infancy, when there are many vaccinations performed, and the intervals between the doses are short. In addition, by implementing a mandatory IP with conjugated vaccines you can enrich the number of doses of some components. This applies to hexavalent vaccines that contain in their composition antigens of Poliomyelitis and hepatitis B, since vaccination regimens of the manufacturer indicate four-times using the product according to the scheme of DTP vaccination, while the monovalent vaccinations of Poliomyelitis (IPV) and hepatitis B in the Polish IP are performed three times $[1,5,6]$.

In countries with high health care standards, fiveand six-component vaccines have been used for many years, and by the fact that they improve the implementation of IP, the acceptance of vaccinations and their implementation have increased in these countries [2]. Many parents support the conjugated vaccines in Poland, as in addition to the benefits of the vaccinations, diminishing of the child's unpleasant sensations associated with the injection is also important. Despite the high costs of these preparations, many parents choose an alternative of IP with a conjugated vaccine for their child [8].

The most significant modifications in the Polish IP that have taken place over the last 10 years included: the replacement of the monovalent vaccines against measles and rubella with the combined vaccine; the introduction of vaccination against Poliomyelitis with vaccine IPV (in place of a live vaccine OPV) in the first two years of life; the routine use of vaccination against pertussis with acelular pertussis component for children aged 6 years and for premature infants; the introduction of universal vaccination against invasive infections caused by bacillus of Haemophilus influenzae type $\mathrm{b}$; implementation of vaccination against Streptococcus pneumoniae and varicella zoster virus in risk groups [9].

\section{VACCINOLOGY EDUCATION - THE CURRENT PRACTICAL DIMENSION}

Health education carried out by a nurse in the vaccination office relates primarily to the promotion, also as a part of a healthy lifestyle promotion. The acceptance of vaccination being the primary method of infectious diseases prevention is essential for the way of performing IP in a given population. Still, implemented and improved vaccines make this method more effective and safe. However, some parents are reluctant to expose their children to vaccinations, even mandatory ones, among other things, because they are the cause of the iatrogenic stress and pain [10]. Discomfort associated with a visit to the vaccination office and administered vaccine preparations are compensated by the efforts of medical staff, professional and loving care and warm atmosphere.

Another reason for not accepting vaccines is sometimes the possibility of an adverse reaction after vaccination (AR). The experience is even the more difficult that healthy children experience vaccination. For a parent, vaccinations are primarily aimed to prevent an infectious disease in their children. In this situation, the acceptance of the AR is difficult, especially since most vaccinations are performed in infancy and early childhood. Therefore, the knowledge given to parents about immunization must be accurate and supported by facts. Parents should be aware of the possibility of developing AR, but simultaneously should be informed about the risk of potential hazards resulting from contracting an infectious disease [11].

It is extremely important to constantly remind parents about the currently applicable IP and the type and date of the subsequent vaccination. While providing information on mandatory vaccinations, nurses draw parents' attention to the need of implementing the full immunization scheme, and not 
manipulating the date of vaccinations, or resignation of specific doses [8].

All parents are informed about the right to choose to type of vaccines they want to give to their child. Knowledge about the recommended vaccines and the possibilities of supplementing the mandatory vaccinations with them is also important. The costs of recommended vaccines are covered by the parents or child-minders. Therefore, it is important to emphasize the economic aspect of prevention; however, even vaccination paid by the parent is always cheaper than the cost of any treatment of diseases and complications that may occur in the course of an infectious disease. Transfer of knowledge to parents by the doctor and the nurse is done at every possible occasion. This has a significant impact on the opinion about vaccinations, and it is important that this information should be presented in a way that is understandable and accessible to parents. In addition to individual interviews with parents in the vaccination office, promoting sometimes takes the form of educational meetings for children and their parents in schools [7, 12].

\section{THE ASSUMPTIONS OF MODERN VACCINOLOGY EDUCATION}

An important element influencing the immunization policy in the country is the degree of acceptance by society. Insufficient or incorrect information on vaccination substantially affect the perception of the methods of prevention of infectious diseases [8]. The dynamic situation in recent years in the implementation of effective immunoprophylaxis in Poland, the aim of which is to further develop IP according with the trends in European countries, creates the need for reliable and ongoing education about vaccinations. This requires from the medical staff (a doctor and a nurse) not only current knowledge about vaccination, but also the ability to communicate effectively and build a feeling of trust in the relationship with the patients and their parents. As shown by recent studies in Poland in the sphere of decisions about immunization, medical staff is the most reliable source of information about them $[6,9$, 10, 13].

Legal interpretation of the profession of a nurse and midwife indicates the professional obligation to take up the activities on health promotion and disease prevention, which include education on the compulsory vaccinations and information on recommended vaccinations. Furthermore, the need for education about vaccination is a privilege arising from the professional competencies of nursing personnel, because according to the standards of education, they are prepared to provide services in terms of health promotion and disease prevention. At the same time, there is still a need for effective organization and implementation of immunization [14, 15, 16, 17].

In the context of human health, the theoretical foundation of modern vaccinology education should be perceiving it as a process, the purpose of which is the acquisition and development of human competence to effectively influence own health and the health of community which he lives in $[12,18]$.

In traditional terms, vaccinology education, as part of health education deals primarily with providing the educated population with knowledge about vaccination, but in modern terms it should be a process of education, which leads to the development of competence in population trained, i.e. knowledge, skills, disposition and attitudes and values necessary for the realization of the tasks related to health. The vaccinology education provided in such a way results in obtaining competencies in vaccinology by the population trained, which, as a result of a deliberate process of education, gives reliable knowledge needed for making effective decisions, expressing judgments and actions on matters related to immunization [3, 19].

The most important features of modern vaccinology education is planning and performing a series of organized activities, in which there are stages of diagnosis, planning and implementation and evaluation. Such a process of education requires personal commitment from the educator and conviction of the rightness of the information provided. In addition, it necessitates good substantive preparation and continuous improvement of own competencies and creates the need for development of interpersonal communication skills. At the same time this way of conducting education requires interdisciplinary action [20].

Current vaccinology education is carried out by the primary health care (PHC) doctor, who initiates the genesis of education, and by the nurse in the immunization office, where the population trained should continue and approve the initiated process of acquisition of vaccinology competencies. In the PHC office, the scope of education comprises vaccination of children, adults and the elderly - mandatory and 
recommended, the current changes in the IP, and the alternative ways of implementing IP and information about vaccinations for travelers. In the immunization office nurses primarily perform the vaccination according to the established procedure, carry out postvaccinal observation, inform what to do in case of local reactions (redness and swelling) and document the performed vaccinations. An important element of a good partnership with parents is primarily limiting unpleasant sensations of a child. If necessary, nurses inform about the mandatory and recommended vaccinations specifying the date of their implementation [7].

PHC doctor and nurse from the office of vaccination should cooperate with medical staff of other specialties in the field of vaccinology education. Depending on the medical specialization of the person carrying out education, the area of cooperation should be adapted. An important part of vaccinology education for the obstetrician, gynecologist, neonatologist, nurse and midwife who looks after a woman and her child should be a transfer of knowledge and development of competencies concerning vaccinations in pregnancy, vaccinations of premature infants and younger children, and vaccination against infection with human papillomavirus (HPV) of girls and young women, as well as influenza vaccination of women planning pregnancy and of the young children. Community nurses carry out vaccinology education of their clients regarding vaccinations of the elderly against influenza, rabies (post-exposition), tetanus of persons injured and vaccination recommended in risk groups. However, the nurse in her education environment should participate in the education of young people about vaccination against pneumococcal, meningococcal, pertussis and HPV [20].

Vaccinology education as a series of organized activities should not be random. It always requires firstly to identify the vaccinology problems, then determine the manner of education and evaluation of results. The most preferred form of education is a personal conversation (explanation, instruction), transfer of educational literature with the use of multimedia packages. The collective forms of communication, i.e., talks, speeches, lectures, didactic films are less favorable but possible in certain situations, such as in a school. Also, it is important that in every therapeutic team in the primary care physician practice there should be an appointed person or group of persons, medical professionals, so-called vaccinology educators who would be responsible for the implementation of education as a series of organized activities leading to the acquisition of relevant competencies in the trained people and cooperating in the field of the education with other health professionals $[11,12,21]$.

A very important element of properly carried out vaccinology education is always the first meeting with the child's parents or other persons who are to decide on the implementation of the vaccination. Very often, parents and other people who want to be vaccinated have better and better knowledge about the prevention of infectious diseases. In addition, they have a positive or negative attitude to vaccination. When they contact with the doctor and a nurse they share their fears or concerns, they are often not ready to make a decision as to the type of vaccinations, or on the contrary already have their own suggestion for the scope of immunization. The decision about the possibility of the active prevention is always taken by the child's parents, because all questions and concerns reported by the parents should be replied in a substantially straightforward manner, calmly and with empathy. This attitude and form of knowledge transfer will help parents to make an informed consent and take optimal decisions about their child's strategy of immunoprophylaxis [7, 22, 23].

Providing information on mandatory and recommended vaccinations should not be limited to a single talk during the first inoculation visit, confirmed by a note in the medical records. The subject of compulsory and recommended vaccinations that extend the prevention of infectious diseases should also appear during subsequent meetings with parents. Some vaccinations are mandatory on the later stages of child development. Moreover, the decisions of parents may be influenced by new information, and often there appear more or less serious illnesses, reactions or other unexpected situations in the child's development, which constitute an additional obstacle in the implementation of vaccination in accordance with the IP or patterns arising from the summaries of product characteristics of individual preparations. In such a situation there must always be an individual adaptation of IP that is suitable for the needs of a particular child [6].

It seems that the areas of vaccinology education that require ordering to make the system of information transfer aimed at equipping parents with the healthrelated competencies for rational deciding on matters 
of their own health and their loved ones, is a need for new organizational solutions in institutions of family doctor. The effect should be setting up teams and education leaders concerning vaccination, then the improvement of interpersonal communication skills, taking care of unanimity in the transfer of information about immunization, developing team skills and the constant quest for scientifically justified knowledge $[10,13]$.

A very important element in increasing the effectiveness of the vaccinology education process conducted by a vaccinology nurse/educator is having interpersonal communication skills and adhering to the guidelines of effective education based on research findings. Among them, the most important is adjusting the scope of information individually for each parent /minder, in an orderly manner, with using standard materials and prepared exclusively for the person educated. It is also important to make sure that the parent is composed and set to perceiving information, because the high emotional arousal can lead to disruption of the process of communication and decision-making capacity. Maintaining of a good relationship with the educated personfosters positive motivation to seek scientifically based information about immunization [22, 23, 24].

The result of a well-conducted vaccinology education should be to strive to reduce infectious diseases and their complications, increase population immunity and a better quality of family, economic and social life.

\section{CONCLUSIONS}

Promoting social attitudes concerning the health and prevention of infectious diseases is an important priority of the recommended prevention activities. The implementers of mandatory and recommended vaccinations are medical professionals employed in primary health care. One of the conditions for their effective implementation is professional vaccinology education, i.e. demonstrating empathy towards the fears and concerns of parents and arranging lectures/speeches about the benefits and the risks of vaccinations. This task largely depends on individual predisposition to pursue education, training and experience, and regular updating of professional knowledge in the field of vaccinology. Conducting vaccinology education in a planned manner, in accordance with the principles of the structured activity cycle, has a significant impact on change of parents' attitudes and overcoming barriers such as lack of acceptance of vaccinations.

\section{REFERENCES}

1. Hryniewicz W. Szczepienia ochronne: co i dlaczego monitorować. Przegl Epidemiol. Państwowy Zakład Higieny. Warszawa 2003, 57: 63-67.

2. Ślusarczyk J. Problematyka szczepień w krajach Unii Europejskiej. Przegl Epidemiol. Państwowy Zakład Higieny. Warszawa 2003, 57: 97-101.

3. Charońska E. Podstawy teoretyczne edukacji zdrowotnej. [w:] Andruszkiewicz A, Banaszkiewicz M. (red). Teoretyczne podstawy promocji zdrowia, tom 1 . Wyd. Czelej, Lublin, 2008.

4. Augustynowicz A, Wrześniewska-Wal I. Aspekty prawne obowiązkowych szczepień ochronnych u dzieci. Ped Pol. 2013; 88: 120-126.

5. Czajka H. Alternatywny program szczepień i szczepionki skojarzone w praktyce pediatrycznej. Przegl Epidemiol. Państwowy Zakład Higieny. Warszawa 2004, 58, 112114.

6. Bernatowaka E. Szczepionki wysokoskojarzone - nowy plan strategiczny dla szczepień obowiązkowych w Programie Szczepień Ochronnych. Standardy Medyczne/Pediatria 2011, 6 (8): 895-908.

7. Czajka H, Sawiec P. Od Program Szczepień Ochronnych do indywidualnych rozwiązań. Medycyna Praktyczna/Szczepienia (wydanie specjalne), 2013, 3: 3643.

8. Tarczoń I, Dromadzka E, Czajka H. Co na temat szczepień ochronnych wiedzą rodzice i pracownicy ochrony zdrowia? Przegl Lek. 2009; 1-2: 27-33.

9. Mrożek-Budzyn D. Ewolucja polskiego programu szczepień ochronnych na przestrzeni ostatnich 10 lat. Przegl Epidemiol. 2012; 66: 107-112.

10. Rogalska J, Augustynowicz E, Gzyl A, i wsp. Źródła informacji oraz wiedza rodziców na temat szczepień ochronnych w Polsce. Przegl Epidemiol. 2010; 1: 83 - 90

11. Kochman D, Rudzińska T. Znaczenie edukacji rodziców w kontekście szczepień obowiązkowych i zalecanych u dzieci w wieku 0-2 lat. Probl Pielęg. 2008; 16 (1-2): 163172.

12. Woynarowska B. Edukacja zdrowotna. Wydawnictwo Naukowe PWN, Warszawa 2008.

13. Jak rozmawiać $\mathrm{z}$ rodzicami o szczepieniach dzieci. Praktyczny przewodnik dla lekarzy i pielęgniarek. Medycyna Praktyczna/Szczepienia (wydanie specjalne), 2013, 3: 3-27.

14. Rozporządzenie Ministra Zdrowia z dnia 20 października 2005 r. w sprawie zakresu zadań lekarza, pielęgniarki i położnej podstawowej opieki zdrowotnej (dz. u. nr 214, poz. 1816).

15. Ustawa o zawodach pielęgniarki i położnej - DzURP 1996, nr 19.

16. Rozporządzenia Ministra Zdrowia z dnia 19 grudnia 2002 r. w sprawie wykazu obowiązkowych szczepień 
ochronnych oraz zasad przeprowadzania i dokumentacji szczepień (Dz. U. z 2002 r. Nr 237, poz. 2018 z późn. $\mathrm{zm}$.).

17. Ustawa z dnia 5 grudnia 2008 r. o zapobieganiu oraz zwalczaniu zakażeń i chorób zakaźnych u ludzi (Dz. U. Nr 234, art. 67 pkt 3, poz. 1570).

18. Szewczyk T.. Specyficzne cechy edukacji zdrowotnej. [w:] Głowacka M D, Promocja zdrowia. Konteksty społeczno - kulturowe, (red.) Wyd. WOLUMIN s. c., Poznań, 2000.

19. Austvoll-Dahlgren A, Helseth S. What informs parents'decision-making about childhood vaccinations? J Adv Nurs 2010; 66 (11):2421-2430.

20. Malewski M. Modele pracy edukacyjnej z ludźmi dorosłymi. Teraźniejszość - Człowiek - Edukacja. 2000, 1 (9): 47-63.

21. Leask J., Kinnersley P, Jackson C. Communicating with parents' about vaccination: a framework for health professionals. BMC Pediatrics, 2003; 111: 653-659.
22. Stewart J. Mosty zamiast murów. O komunikowaniu się między ludźmi. Warszawa PWN, 2000: 78-86.

23. Whitehead D. Incorporating socio-political health promotion activities into clinical practice. J Clin Nurs 2003, 12, 668-677.

24. Kuchar E, Szenborn L. Postawy antyszczepionkowe i możliwości polemiki. Przew Lek. 2010; 5: 63-66.

Address for correspondence:

Anna Bednarek

20-258 Lublin 62

Sobianowice $85 \mathrm{~F}$

e-mail: bednarekanna@o2.pl

tel. 607607115

Received: 18.11.2014

Accepted for publication: 17.03.2015 